\title{
Bioclimatic zoning of the territory of Ukraine based on human thermal state
}

\section{assessment}

\author{
Liudmyla Malytska \\ Ukrainian Hydrometeorological Institute, Prospekt Nauky 37, 03028 Kyiv, Ukraine, e-mail: m_alitsk_a@i.ua \\ Stanislav Moskalenko \\ Taras Shevchenko National University of Kyiv, Volodymyrska Street 60, 01033 Kyiv, Ukraine
}

\begin{abstract}
This research focuses on objective assessment of bioclimatic conditions through analyses of biometeorological indices based on Harrington's desirability function. Evaluation criteria for the Harrington desirability function during winter are: Bodman's winter severity index (S), equivalent-efficient temperatures (EETA), index of wind cooling $\left(K_{0}\right)$, and wind chill temperature $(W C)$. These metrics were integrated into one complex, generalized desirability index for winter $(D W)$. For the summer period, equivalentefficient temperatures of Missenard (EET) index, radiation equivalent-effective temperature (PEET) and Heat Index (HI), were combined to form a desirability index for summer $(D S)$. Zoning of the territory by e integrating the indices $(D W / D S)$ portrays the seasonal and spatial differentiation of bioclimatic conditions over Ukraine. These differences were used to highlight the most favorable and unfavorable regions (zones) for humans and, accordingly, the level of bioclimatic resources for each region. In winter across Ukraine, four zones with different levels of weather comfort were identified, with only three zones in summer. For both seasons meteorological conditions are mostly comfortable based on human thermal state. Zone 3, with satisfactory bioclimatic resources and comfortable weather, is the largest of all zones in both winter and summer, making up 49.61\% and 61.0\% Ukraine's territory, respectively. Average values of climatic characteristics were calculated for the specified zones for both seasons (1981-2010).
\end{abstract}

Keywords

Bioclimatic conditions, Harrington Desirability function, biometeorological indices, human thermal state.

Submitted 16 April 2019, revised 19 July 2020, accepted 27 July 2020 DOI: $10.26491 / \mathrm{mhwm} / 125755$

\section{Introduction and background}

Meteorological conditions affect the human thermal state. To assess this effect, scientists use indicators that describe certain aspects of influence: thermal load, thermal stress, wind cooling, and others. These indicators are known as biometeorological indices (Epstein, Moran 2006). Throughout the twentieth century and into the twenty-first century there has been an active development of these indices (Epstein, Moran 2006). However, the question of the impact of weather and climate on the state of human health remains open, and scientists of various countries investigate it (Kalkstein, Davis 1989; Kalkstein 2001; Mohan et al. 2014; Frohlich, Matzarakis 2015), indicating a considerable interest in this topic. Their works describe the mechanisms of how climate influences humans, especially, morbidity and mortality, the problems of acclimatization, as well as the possibility of applying natural bioclimatic resources for the prevention and treatment of diseases of various organs and their systems, etc. Matthies et al. (2011) noted a significant increase in deaths during heatwaves. 
An important task of modern bioclimatology is to evaluate the properties of the climate in terms of favorable or unfavorable conditions for human life based on bioclimatic resources ${ }^{1}$ (Jendritzky et al. 2007). The assessment of such resources requires the development of a universal index that would allow taking into account the accumulation of negative effects of the meteorological condition on human thermal comfort. Work toward the development of such an index has been underway since 2005 as a part of the project COST Action 730. The working title of the index is "Universal Thermal Climate Index" (UTCI), currently still under development. Frohlich and Matzarakis (2015) conducted a comparative analysis of UTCI, PET (physiologically equivalent temperature) and PT (perceived temperature). They showed the indices' applicability and reliability in hot and windy conditions by analyzing their distribution and sensitivity under the given conditions based on the modification of a real data set. Scientists have concluded that none of the tested indices meets all requirements for a universal index, but they can be used to solve various applied problems of biometeorology. The indices should therefore be improved to be valid for several kinds of climates (Frohlich, Matzarakis 2015).

In Ukraine, the assessment of bioclimatic resources is a priority area of research in applied meteorology (Strategy of Sustainable Development "Ukraine - 2020", 2015). Complex studies of the thermal comfort regime, its features in the summer and winter periods, and the assessment of the effects of climate change on human health are highlighted in works of Stepanenko et al. (2011, 2015). However, it should be noted that maps for generalizing these characteristics into a single-scale bioclimatic resource are not presented. The aim of this article is to study the spatial distribution of bioclimatic conditions through analyses of biometeorological indices by seasons (winter and summer), based on the Harrington Desirability function in Ukraine (1981-2010).

\section{Data and methods}

\subsection{Dataset}

The research was conducted for the period of 1981-2010 using daily data for temperature, wind speed, and humidity from the 187 meteorological stations across the Ukraine. Data were provided by the Central Geophysical Observatory (www.cgo.kiev.ua).

For spatial distribution (mapping) we used an open source geographic information system (QGIS modification 3.4.3 Madeira). Interpolation of data was carried out using the inverse distance weighted method (IDW interpolation).

\subsection{Methods}

To comprehensively assess bioclimatic resources and develop a universal index, it is necessary to combine the bioclimatic indices that characterize various aspects of the influence of the meteorological conditions

\footnotetext{
${ }^{1}$ In general, "climatic resources" are a supply of matter, various types of energy, and information about the atmosphere and the topsoil that can be used to solve specific problems aimed at improving human living standards and creating material goods (Kobysheva 2008). The climatic properties favorable for human life create bioclimatic resources.
} 
on the human thermal state. As a rule, multiple bioclimatic indices are used for this purpose. They use different scales that complicate comparison and generalization. Harrington's desirability function allows not only normalization of certain factors, but also integration of them into a one index that determines the most favorable or unfavorable conditions following established criteria (Harrington 1965).

The Harrington desirability function (Hdf) takes values from 0 to 1 (Table 1 ). Value 0 is the worst value of the index, reflecting extremely uncomfortable weather conditions, with the greatest thermal load on humans and an unacceptable level of bioclimatic resources. Value 1 reflects extremely comfortable conditions with the least thermal load and an excellent level of bioclimatic resources.

Table 1. Description of the level of bioclimatic resources of the human thermal state through the function of Harrington's desirability index (compiled by the authors based on Harrington 1965).

\begin{tabular}{|l|l|l|}
\hline$H d f$ value & The degree of weather comfort & Level of resource \\
\hline $0.81-1.00$ & extremely comfortable & excellent \\
\hline $0.64-0.80$ & very comfortable & good \\
\hline $0.38-0.63$ & comfortable & satisfactory \\
\hline $0.21-0.37$ & uncomfortable & unsatisfactory \\
\hline $0.00-0.20$ & extremely uncomfortable & unacceptable \\
\hline
\end{tabular}

Since heat exchange between the human body and the environment differs in warm and cold periods with different meteorological conditions, it is advisable to make assessments separately for each period, according to the Harrington desirability function ( $D W$ for the winter and $D S$ for the summer). The average values of climatic characteristics for 1981-2010 were calculated for selected zones.

\subsection{Calculation of $D W$}

In the winter period it is advisable to account for the severity of the season, human heat loss due to cooling through the combined action of wind and low temperatures, thermal sensation, and heat transfer of the human body for certain values of wind speed, temperature, and air humidity, etc. For this purpose, we used the following biometeorological indices: the Bodman winter severity index $(S)$, equivalentefficient temperatures of Missenard (EET), and Eisenstadt (EETA), index of wind cooling $\left(K_{0}\right)$ by Siple and Passel, wind chill temperature (WC) (Siple, Passel 1945; OFCM 2003; Kobysheva 2008).

For each observation station, for all selected bioclimatic indices we calculated their average long-term values for the winter $\bar{x}$ ) 1981-2010. The next step was to choose maximum permissible limits $\left(\chi_{0}, x_{1}\right)$ for the "satisfactory" zone. Then partial functions of desirability $-d(s)$ were established. Based on these functions, we calculated the generalized desirability index $D W$, reflecting the level of bioclimatic resources of the human thermal state in the winter period that correspond to a certain degree of weather comfort: 


$$
\begin{aligned}
& D W=\left(d S * d K_{0} * d E E T * d E E T A * d W C\right)^{\frac{1}{5}} \\
& d S=\exp \left(-\exp \left(-\left(x_{0}-S\right) /\left(x_{0}-x_{1}\right)\right)\right) \\
& d K_{0}=\exp \left(-\exp \left(-\left(x_{0}-K_{0}\right) /\left(x_{0}-x_{1}\right)\right)\right) \\
& d E E T=\exp \left(-\exp \left(-\left(x_{0}-E E T\right) /\left(x_{0}-x_{1}\right)\right)\right) \\
& d E E T A=\exp \left(-\exp \left(-\left(x_{0}-E E T A\right) /\left(x_{0}-x_{1}\right)\right)\right) \\
& d W C=\exp \left(-\exp \left(-\left(x_{0}-W C\right) /\left(x_{0}-x_{1}\right)\right)\right)
\end{aligned}
$$

where: $D W$ - generalized desirability index in winter; $d S, d K_{0}, d E E T, d E E T A, d W C$ - the partial feedback of Harrington desirability functions of the Bodman winter severity index $(S)$, index of wind cooling $\left(K_{0}\right)$, equivalent-efficient temperatures of Missenard (EET), and Eisenstadt (EETA), wind chill temperature $(W C) ; x_{0}, x_{1}-$ minimum and maximum allowable values of the characteristic in the "satisfactory" zone.

The limits of the "satisfactory" zone $\left(x_{0}, x_{1}\right)$ were established in accordance with the scales of heat perception and heat loss of bioclimatic indices (Table 2). The interval $\left[x_{0} \ldots x_{1}\right]$ is conventionally accepted as a range within which the weather is comfortable and on the Harrington scale of desirability corresponds to the critical points $d\left(x_{0}\right)=0.37$ and $d\left(x_{1}\right)=0.64$.

Table 2. The limits of the "satisfactory" zone according to bioclimatic indices (winter period) (compiled by the authors based on Kobysheva et al. 2008).

\begin{tabular}{|l|c|c|}
\hline \multirow{2}{*}{ Bioclimatic index } & \multicolumn{2}{|c|}{ Limits of "satisfactory" zone } \\
\cline { 2 - 3 } & $x_{0}$ & $x_{1}$ \\
\hline Bodman's winter severity index $S$, unit & 3 & 2 \\
\hline index of wind cooling $K_{0} \mathrm{kcal} /\left(\mathrm{h} \cdot \mathrm{m}^{2}\right)$ & 1000 & 799 \\
\hline equivalent-efficient temperatures of Missenard, $E E T,{ }^{\circ} \mathrm{C}$ & -12 & -6 \\
\hline equivalent-efficient temperatures of Eisenstadt, $E E T A,{ }^{\circ} \mathrm{C}$ & -17 & -11 \\
\hline wind chill temperature $W C,{ }^{\circ} \mathrm{C}$ & -27 & -10 \\
\hline
\end{tabular}

\subsection{Calculation of $D S$}

To evaluate the human thermal state in summer and assess the level of bioclimatic resources we used the equivalent-efficient temperatures of Missenard (EET), radiation equivalent-effective temperature (PEET) and Heat Index (HI) (Kobysheva et al. 2008; Mohan et al. 2014). The limits of the "satisfactory" zone are presented in Table 3. Partial feedback of desirability functions and generalized desirability index in summer were calculated according to the formulas:

$$
\begin{aligned}
& D S=(d E E T * d P E E T * d H I)^{\frac{1}{3}} \\
& d E E T=\exp \left(-\exp \left(-\left(x_{0}-E E T\right) /\left(x_{0}-x_{1}\right)\right)\right) \\
& d P E E T=\exp \left(-\exp \left(-\left(x_{0}-P E E T\right) /\left(x_{0}-x_{1}\right)\right)\right) \\
& d H I=\exp \left(-\exp \left(-\left(x_{0}-H I\right) /\left(x_{0}-x_{1}\right)\right)\right)
\end{aligned}
$$

where: $D S$ - generalized desirability index in summer; $d E E T, d E E T, d H I$ - the partial feedback of Harrington desirability functions of equivalent-efficient temperatures of Missenard (EET), radiation 
equivalent-effective temperature (PEET) and Heat Index (HI); $x_{0}, x_{1}$ - minimum and maximum allowable values of the characteristic in the "satisfactory" zone.

Table 3. The limits of the "satisfactory" zone by bioclimatic indices (summer period).

\begin{tabular}{|l|c|c|}
\hline \multirow{2}{*}{ Bioclimatic index } & \multicolumn{2}{|c|}{ Limits of “satisfactory" zone } \\
\cline { 2 - 3 } & $x_{0}$ & $x_{1}$ \\
\hline equivalent-efficient temperatures of Missenard EET, ${ }^{\circ} \mathrm{C}$ & 18 & 12 \\
\hline radiation equivalent-effective temperature $P E E T,{ }^{\circ} \mathrm{C}$ & 21 & 17 \\
\hline Heat Index $(H I),{ }^{\circ} \mathrm{F}$ & 90 & 80 \\
\hline
\end{tabular}

\section{Results}

\subsection{Assessment of bioclimatic resources of the human thermal state in winter}

\section{(December, January, February)}

The analysis of the generalized desirability index in winter (DW) and its partial feedbacks showed that in Ukraine winter meteorological conditions are mostly comfortable for the human thermal state. Partial feedbacks of $H d f$ for the five selected bioclimatic indices are presented in Figure 1. They illustrate the relationship between the quantitative values of the dimensionless scale that match psychological perception of a person on one side and values of bioclimatic indices on the other. Values of desirability are on the ordinate axis, with the values of the characteristics under study along the abscissa. The $\mathrm{x}$-axis also illustrates the range of the values of bioclimatic indices in Ukraine.
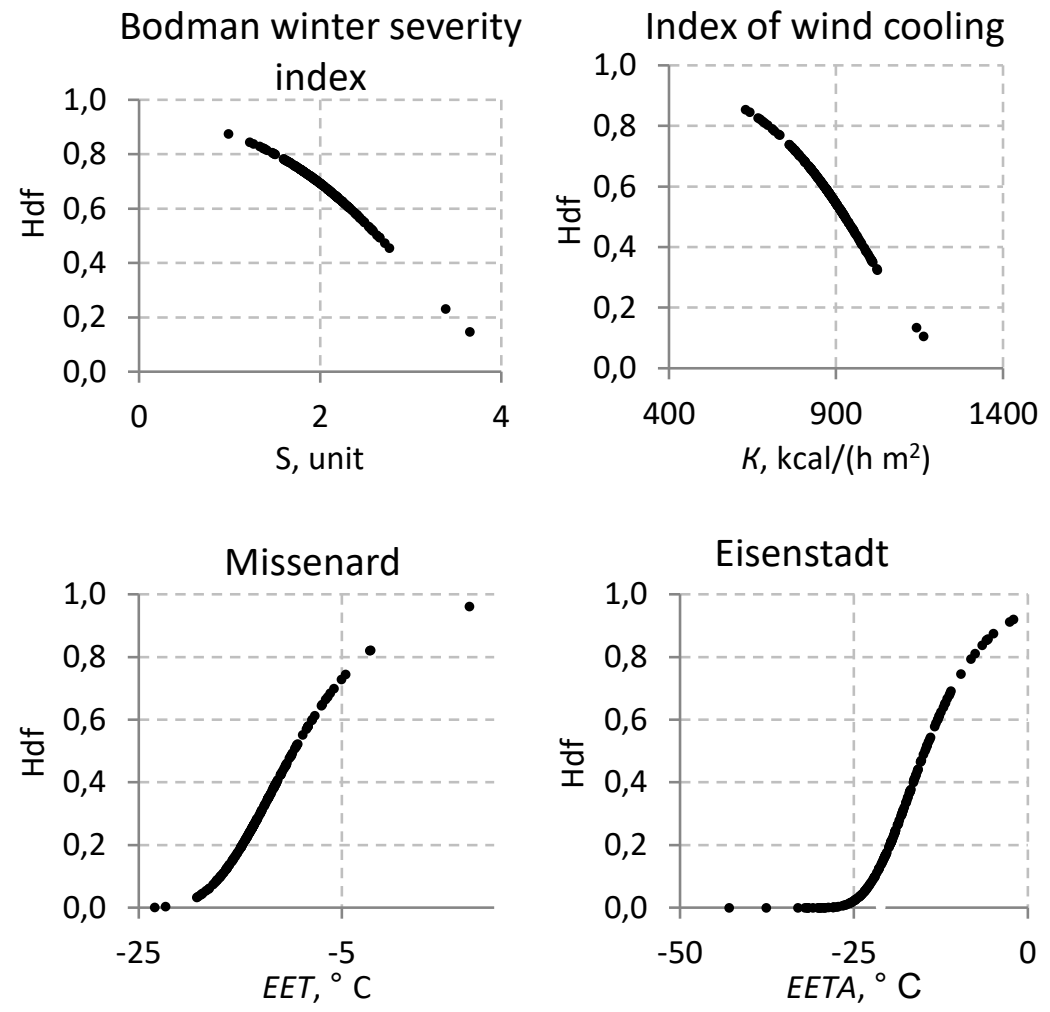


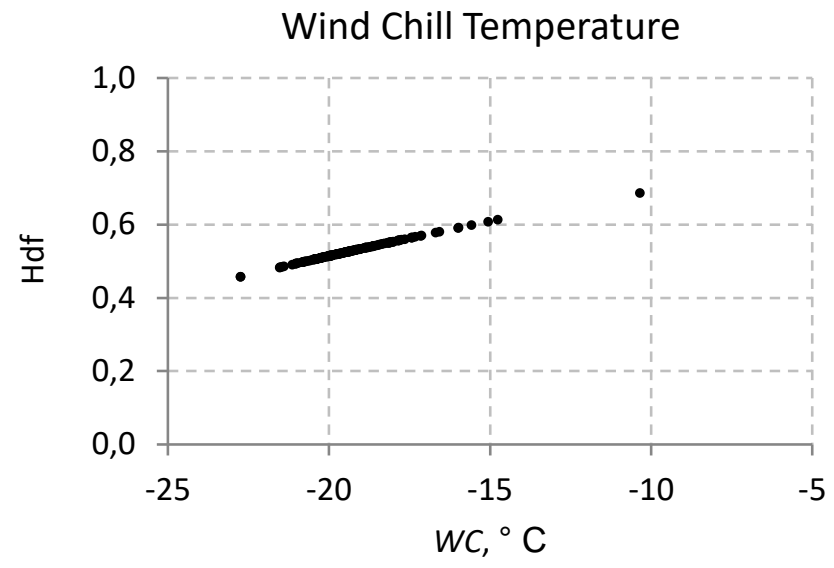

Fig. 1. Harrington partial functions $(H d f)$ of desirability for bioclimatic indices (average long-term values for the winter of 1981-2010).

The values of indices that lie beyond the limit of 0.63 on the scale of desirability correspond to very comfortable environment conditions for a person, and values of 0.37 and below match uncomfortable weather conditions, when the body's thermoregulation system is in a state of stress (Table 1).

The zoning of the Ukraine territory according to the integrated index of $D W$ has identified four zones with different levels of bioclimatic resources and comfort of weather conditions.

Based on $D W$ values during winter, extreme weather discomfort and the lowest level of bioclimatic resources occur in the mountainous regions of the Carpathians, the eastern (Donetsk ridge area, Fig. 2) and northeastern regions of the country (Zone 1 on Figure 3). This zone occupies an area of $43,824 \mathrm{~km}^{2}$, or $7.26 \%$ of the territory of Ukraine.

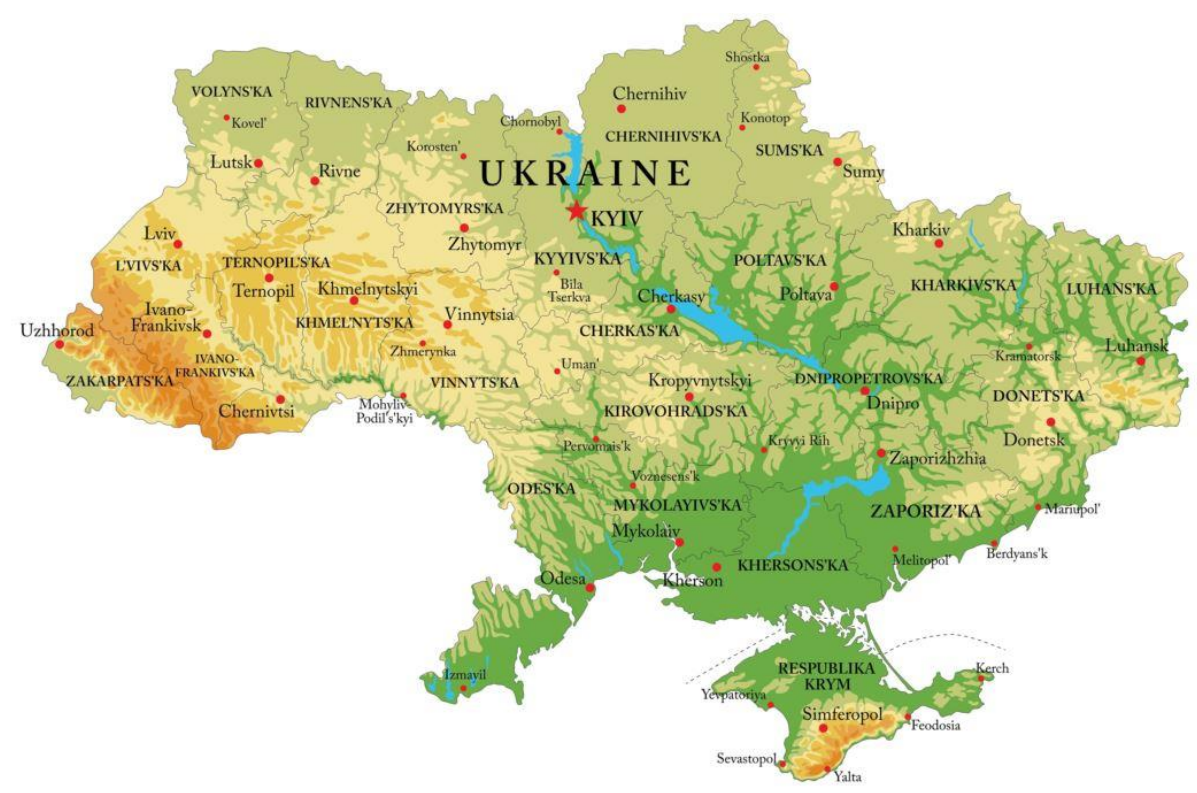

Fig. 2. Physical-geographical map of Ukraine. 


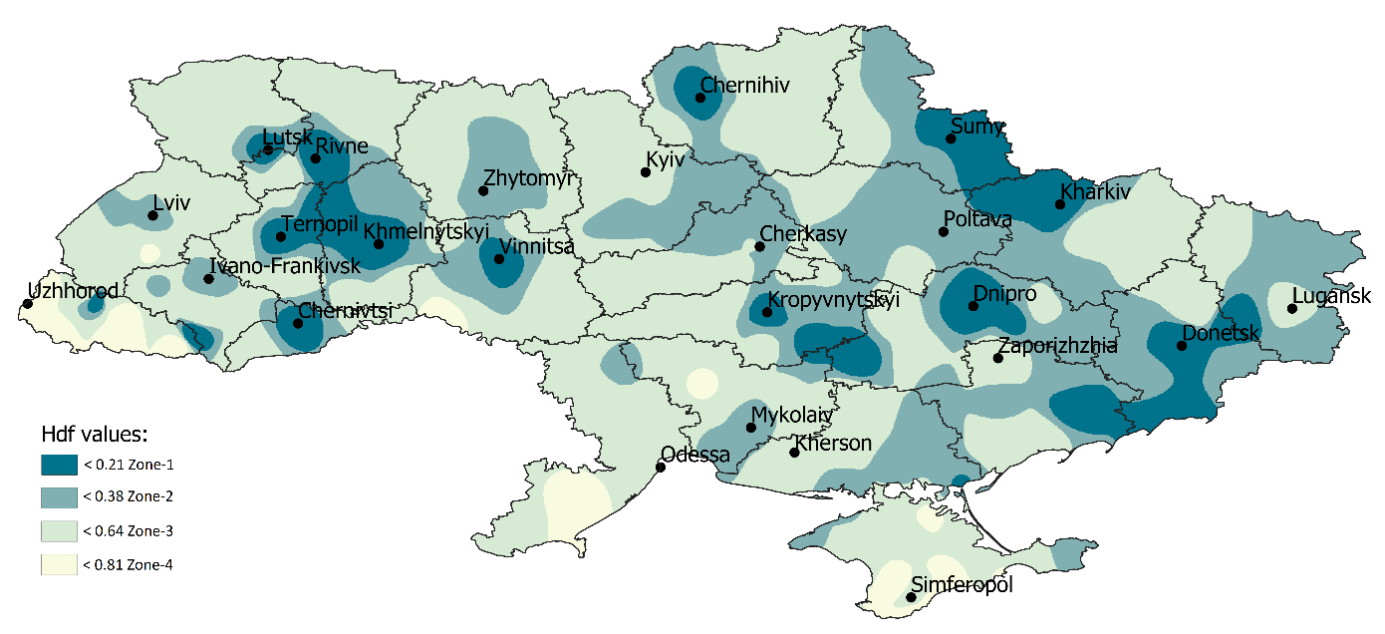

Fig. 3. Spatial distribution of $D W$ values (1981-2010) across Ukraine.

The values of the generalized function $D W$ in this zone are in the interval [0.0-0.2]. This suggests that most of the bioclimatic indices lie outside the comfort requirement. This territory is characterized by a persistent cold, there is a high risk of overcooling, the duration of being safely outdoors (without the risk of frostbite of open areas of the body) is from 10 to 30 minutes. It was established that across Zone 1, winter is moderately severe, the average seasonal temperature is $-3.4{ }^{\circ} \mathrm{C}$, the mean minimum is $-6.0^{\circ} \mathrm{C}$, and the mean maximum is $-0.7^{\circ} \mathrm{C}$ (Table 4). There are 60 winter days with an average temperature equal or less $0^{\circ} \mathrm{C}$ per day and 33 days with a temperature below $-10^{\circ} \mathrm{C}$. The absolute maximum duration of the period with such temperature may be longer than a month (36 days). In general, there are 3 days per season with temperatures below $-20^{\circ} \mathrm{C}$, although in single years there can be significantly more days below $-20^{\circ} \mathrm{C}$, and the absolute maximum duration of a period with a very low temperature can extend to 8 days. In the long-term, there are six days per season with daily temperature variability $>6^{\circ} \mathrm{C}$. This zone experiences the highest wind speeds, with a long-term average value per season of $4.4 \mathrm{~m} \cdot \mathrm{s}^{-1}$. Zone 1 also has the highest frequency of days with wind speed $\geq 7 \mathrm{~m} \cdot \mathrm{s}^{-1}$ (11 days) and the smallest frequency of calm $\left(0-1 \mathrm{~m} \cdot \mathrm{s}^{-1}\right)$ and light wind $\left(1-4 \mathrm{~m} \cdot \mathrm{s}^{-1}\right)$ conditions: 4 and 39 days, respectively. High wind speeds cause the most rapid losses of heat by the human body due to wind cooling, i.e. $-983 \mathrm{kcal} /\left(\mathrm{h} \cdot \mathrm{m}^{2}\right)$. The region is also characterized by the highest relative humidity in winter (77\%), the lowest values of the EET and EETA $\left(-17.4^{\circ} \mathrm{C}\right.$ and $-28.9^{\circ} \mathrm{C}$, respectively) and the lowest values of cold stress by $W C\left(-20.6^{\circ} \mathrm{C}\right)$.

Table 4. Climatic characteristics of zones with different levels of bioclimatic resources for the human thermal state during the winter period (1981-2010) in Ukraine.

\begin{tabular}{|l|c|c|c|c|}
\hline \multirow{2}{*}{ Characteristics } & \multicolumn{3}{|c|}{ Zones with different levels of bioclimatic resources } \\
\cline { 2 - 5 } & $1 *$ & $2^{*}$ & $3^{*}$ & $4^{*}$ \\
\hline average temperature, ${ }^{\circ} \mathrm{C}$ & -3.4 & -2.7 & -2.3 & 0.5 \\
\hline mean minimum temperature, ${ }^{\circ} \mathrm{C}$ & -6.0 & -5.4 & -5.2 & -2.4 \\
\hline mean maximum temperature, ${ }^{\circ} \mathrm{C}$ & -0.7 & 0.2 & 0.8 & 4.0 \\
\hline
\end{tabular}




\begin{tabular}{|c|c|c|c|c|}
\hline \multirow{2}{*}{ Characteristics } & \multicolumn{4}{|c|}{ Zones with different levels of bioclimatic resources } \\
\hline & $1 *$ & $2^{*}$ & $3 *$ & $4^{*}$ \\
\hline number of days with $T_{a v} \leq 0^{\circ} \mathrm{C}$, days & 60 & 56 & 53 & 37 \\
\hline number of days with $T_{\min } \leq-10^{\circ} \mathrm{C}$, days & 33 & 30 & 29 & 17 \\
\hline number of days with $T_{\min } \leq-20^{\circ} \mathrm{C}$, days & 3 & 3 & 3 & 1 \\
\hline $\begin{array}{l}\text { number of days with daily temperature variability } \\
>6^{\circ} \mathrm{C} \text {, days }\end{array}$ & 6 & 6 & 6 & 5 \\
\hline $\begin{array}{l}\text { absolute maximum duration of the period with } T_{\min } \\
\leq-10^{\circ} \mathrm{C} \text {, days }\end{array}$ & 36 & 34 & 31 & 19 \\
\hline $\begin{array}{l}\text { absolute maximum duration of the period with } T_{\min } \\
\leq-20^{\circ} \mathrm{C} \text {, days }\end{array}$ & 8 & 7 & 7 & 3 \\
\hline average wind speed, $\mathrm{m} \cdot \mathrm{s}^{-1}$ & 4.4 & 3.5 & 2.7 & 2.0 \\
\hline number of days with wind $\geq 7 \mathrm{~m} \cdot \mathrm{s}^{-1}$, days & 11 & 5 & 3 & 2 \\
\hline number of days with wind $0-1 \mathrm{~m} \cdot \mathrm{s}^{-1}$, days & 4 & 5 & 13 & 23 \\
\hline number of days with wind $1-4 \mathrm{~m} \cdot \mathrm{s}^{-1}$, days & 39 & 54 & 61 & 56 \\
\hline average relative humidity, $\%$ & 76.8 & 75.1 & 73.7 & 68.8 \\
\hline Bodman's winter severity index $S$, unit & 2.5 & 2.1 & 1.9 & 1.5 \\
\hline index of wind cooling $K_{0} \mathrm{kcal} /\left(\mathrm{h} . \mathrm{m}^{2}\right)$ & 983 & 910 & 844 & 723 \\
\hline $\begin{array}{l}\text { equivalent-efficient temperatures of Missenard } \\
E E T,{ }^{\circ} \mathrm{C}\end{array}$ & -17.4 & -14.7 & -12.3 & -6.8 \\
\hline $\begin{array}{l}\text { equivalent-efficient temperatures of Eisenstadt } \\
\text { EETA, }{ }^{\circ} \mathrm{C}\end{array}$ & -28.9 & -22.6 & -17.4 & -8.6 \\
\hline wind chill temperature $W C,{ }^{\circ} \mathrm{C}$ & -20.6 & -19.8 & -19.2 & -17.1 \\
\hline
\end{tabular}

$* 1$ - unacceptable level, extreme uncomfortable weather; $* 2$ - unsatisfactory level, uncomfortable weather; $* 3$ satisfactory level, comfortable weather; $* 4$ - good level, very comfortable weather.

It was found that significant levels of discomfort and unsatisfactory bioclimatic resources for the human thermal state are located in Livoberezhno-Dnieper-Pryazovsky Krai, the Carpathian Mountains, the eastern slopes of the Podolsk Hills, and the coastal areas of the Black Sea and Azov Sea (Zone 2 on Fig. 3). The total area of Zone 2 is $252,196 \mathrm{~km}^{2}$, or $41.78 \%$ of the territory of Ukraine. In these regions there is a moderately severe winter with an average temperature of $-2.7^{\circ} \mathrm{C}$. The average minimum temperature is $5.4^{\circ} \mathrm{C}$ and the maximum temperature is above zero, reaching up to $+0.2^{\circ} \mathrm{C}$. In general, according to average values, there are 56 winter days, but the number of days with low temperatures remains high - up to 30 days with a temperature below $-10^{\circ} \mathrm{C}$ and 3 days with a temperature below $-20^{\circ} \mathrm{C}$. However, in anomalously cold years these durations can be longer, the period with frost can reach 34 days, and conditions with temperature below $-20^{\circ} \mathrm{C}$ can last up to 7 days. In Zone 2, there are 6 days with daily temperature variability $>6^{\circ} \mathrm{C}$. The average values of EET and EET $A$ correspond to the categories "cold" and "very cold" $\left(-14.7^{\circ} \mathrm{C}\right.$ and $-22.6^{\circ} \mathrm{C}$ respectively). High average wind speeds $\left(3.5 \mathrm{~m} \cdot \mathrm{s}^{-1}\right)$ cause significant heat losses due to wind cooling. For Zone 2, the index of wind cooling $\left(K_{0}\right)$ is equal to $910 \mathrm{kcal} /\left(\mathrm{h} \cdot \mathrm{m}^{2}\right)$, while the wind chill temperature $(W C)$ is $-19.8^{\circ} \mathrm{C}$. Recreational activities in this area in the winter season are limited by weather conditions and require additional resources for development.

The southern regions of Odessa, the western districts of the Transcarpathian region, and the southern coast of Crimea have the most comfortable weather conditions in winter, as evidenced by the high values 
of $D W$ (Zone 4 in Fig. 3). Zone 4 occupies a small territory, a total area of $8,150 \mathrm{~km}^{2}$, representing only $1.35 \%$ of Ukraine. This zone, with favorable bioclimatic resources for the human thermal state and very comfortable weather, has the highest air temperatures: the seasonal average temperature is $0.5^{\circ} \mathrm{C}$, the average of the maximum $4^{\circ} \mathrm{C}$, and only the minimum temperatures remain below zero $\left(-2.4^{\circ} \mathrm{C}\right)$. In Zone 4 counts of frosty days $\left(T_{\min } \leq-10^{\circ} \mathrm{C}\right)$ and days with strong frost $\left(T_{\min } \leq-20^{\circ} \mathrm{C}\right)$ are $200 \%$ lower than in the rest of Ukraine: 17 and 1 day, respectively. For this zone, low wind speeds are typical, average value $2 \mathrm{~m} \cdot \mathrm{s}^{-1}$. Days with calm conditions or light winds are prevalent. The region also has the lowest relative humidity in winter $(68.8 \%)$, the highest values of the EET and EETA $\left(-6.8^{\circ} \mathrm{C}\right.$ and $-8.6^{\circ} \mathrm{C}$, respectively) and the lowest values of $W C\left(-17.1^{\circ} \mathrm{C}\right)$. According to the indexes of Bodman $(S)$ and wind cooling $\left(K_{0}\right)$, the winters in this zone are not very severe, the category of thermal sensation is "cool" with a slight heat loss of $723 \mathrm{kcal} /\left(\mathrm{h} \cdot \mathrm{m}^{2}\right)$.

The rest of Ukraine (Zone 3 in Fig. 3) during the winter has a satisfactory level of bioclimatic resources for the human thermal state and comfortable weather conditions. This area occupies the largest area$299,460 \mathrm{~km}^{2}, 49.61 \%$ of Ukraine. This zone has non-severe winters with an average temperature of $-2.3^{\circ} \mathrm{C}$, minimum temperature of $-5.2^{\circ} \mathrm{C}$, and maximum of $0.8^{\circ} \mathrm{C}$ (Table 4). The average number of winter days in this region is 53 ; there are 29 days with temperature $\leq-10^{\circ} \mathrm{C}$, and only 3 days per season with temperature $\leq-20^{\circ} \mathrm{C}$. However, in anomalously cold years weather conditions with frost may persist in this territory for a month (31 days). Moderate winds of $2.7 \mathrm{~m} \cdot \mathrm{s}^{-1}$ are typical for this zone, which also has the largest number of days with light winds ( 63 days per season). The average humidity in the winter is $73.7 \%$. Due to the cooling effect of wind and humidity, average values of EET and EETA at $10^{\circ} \mathrm{C}$ and $15^{\circ} \mathrm{C}$ are lower than the average air temperature. They equal $-12.3^{\circ} \mathrm{C}$ and $-17.4^{\circ} \mathrm{C}$, respectively, corresponding to the category of thermal sensation "chilly". The loss of heat by the human body due to wind cooling is $844 \mathrm{kcal} /\left(\mathrm{h} \cdot \mathrm{m}^{2}\right)$.

\subsection{Assessment of bioclimatic resources of the human thermal state in summer (June,}

\section{July, August)}

Analysis of the generalized desirability index DS and its partial feedback showed that in Ukraine summer meteorological conditions are mostly comfortable for humans, and thermal load is moderate. Partial functions of the Harrington desirability function for the three selected bioclimatic indices are presented in Figure 4. 

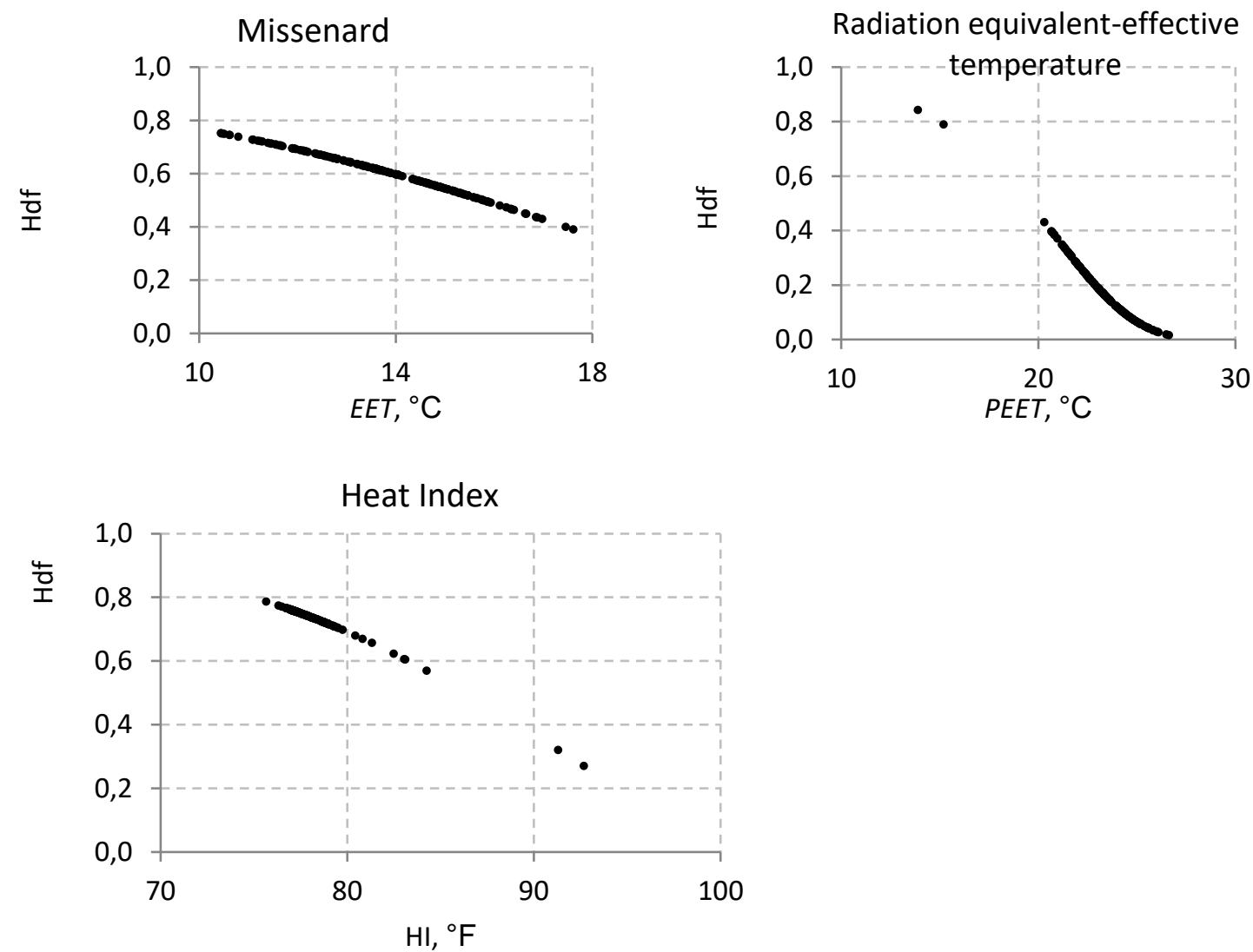

Fig. 4. Harrington partial functions of desirability for bioclimatic indices (average long-term values for the summer of 1981-2010).

Zoning of Ukraine according to the integrated index of $D S$ has identified only three zones with different levels of bioclimatic resources and comfort of weather conditions (Fig. 5). For selected zones the average values of climatic characteristics were calculated for 1981-2010 (Table 5).

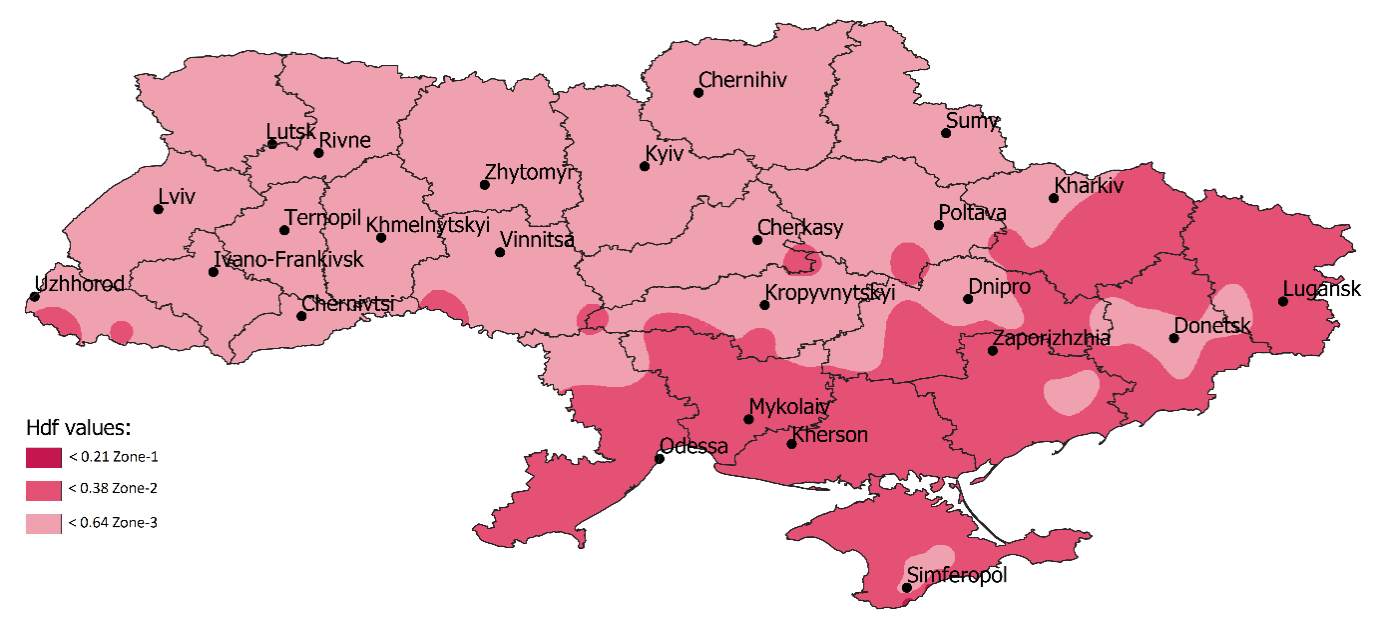

Fig. 5. Spatial distribution of $D S$ values (1981-2010) across Ukraine.

It was found that in summer a considerable level of thermal load and, accordingly, unsatisfactory level of bioclimatic resources for the human thermal state is observed in the southern and the south-eastern 
regions of Ukraine (Zone 2 in Fig. 5). Zone 2 covers an area of 235,294 $\mathrm{km}^{2}, 38.98 \%$ of Ukraine. In this area, the values of bioclimatic indices are $10-20 \%$ higher than the maximum comfort limit. There is overheating of the human body, fatigue, and heat exhaustion during prolonged exposure to the outdoors and physical activity. In this zone, the average summer temperature is $21.4^{\circ} \mathrm{C}$, the average of the maximum $27.2^{\circ} \mathrm{C}$, and the minimum $15.9^{\circ} \mathrm{C}$. The average number of summer days is 86 . Every year 65 days of high temperatures are recorded and the maximum duration of the hot period in some years can be up to 40 days. The load on the body's thermoregulation system is intensified when high air temperatures are maintained not only during the day but also at night. In Zone 2, the average number of tropical nights is 11 (Table 5). During the summer, 4 days with stuffiness are recorded. This region is characterized by the lowest relative humidity (45.5\%), the smallest number of days with comfortable air humidity for humans (within 40-60\%) - only 42 days per season, and the highest values of wind speed $\left(2.3 \mathrm{~m} \cdot \mathrm{s}^{-1}\right)$. Due to the cooling effect of the wind, the value of EET for the comfort zone is $15.3^{\circ} \mathrm{C}$, but the value of PEET exceeds the maximum comfort zone limit at $3.7^{\circ} \mathrm{C}$ (Table 5).

This study revealed that in the summer in Ukraine only individual stations have a complex of meteorological conditions that form unsatisfactory levels of bioclimatic resources for the human thermal state; the overall category of thermal sensation is "moderately cool." Most stations are within the comfortable range with tolerable heat loads.

Table 5. Climatic characteristics of zones with different levels of bioclimatic resources for the human thermal state during the summer period (1981-2010) in Ukraine.

\begin{tabular}{|c|c|c|c|}
\hline \multirow{2}{*}{ Characteristics } & \multicolumn{3}{|c|}{$\begin{array}{c}\text { Zones with different levels of } \\
\text { bioclimatic resources }\end{array}$} \\
\hline & $1 *$ & $2^{*}$ & $3 *$ \\
\hline average temperature, ${ }^{\circ} \mathrm{C}$ & 22.7 & 21.4 & 18.5 \\
\hline mean minimum temperature, ${ }^{\circ} \mathrm{C}$ & 18.6 & 15.9 & 24.4 \\
\hline mean maximum temperature, ${ }^{\circ} \mathrm{C}$ & 27.1 & 27.2 & 13.2 \\
\hline number of summer days with $T_{a v r} \geq 15^{\circ} \mathrm{C}$, days & 90 & 86 & 76 \\
\hline number of hot days with $T_{\max } \geq 25^{\circ} \mathrm{C}$, days & 69 & 65 & 42 \\
\hline $\begin{array}{l}\text { number of tropical nights with } T_{\min } \geq 20^{\circ} \mathrm{C} \text {, } \\
\text { days }\end{array}$ & 31 & 11 & 2 \\
\hline $\begin{array}{l}\text { absolute maximum duration of the period with } \\
T_{\max } \geq 25^{\circ} \mathrm{C} \text {, days }\end{array}$ & 35 & 40 & 15 \\
\hline average relative humidity, $\%$ & 52.7 & 45.5 & 50.7 \\
\hline $\begin{array}{l}\text { number of days with relative humidity within } \\
40-60 \% \text {, days }\end{array}$ & 53 & 42 & 49 \\
\hline number of days with stuffiness, days & 5 & 4 & 2 \\
\hline average wind speed, $\mathrm{m} \cdot \mathrm{s}^{-1}$ & 1.6 & 2.3 & 2.2 \\
\hline $\begin{array}{l}\text { equivalent-efficient temperatures of Missenard } \\
E E T,{ }^{\circ} \mathrm{C}\end{array}$ & 17.5 & 15.3 & 12.6 \\
\hline $\begin{array}{l}\text { radiation equivalent-effective temperature } \\
\left(\text { PEET) },{ }^{\circ} \mathrm{C}\right.\end{array}$ & 26.5 & 24.7 & 22.4 \\
\hline Heat Index $(H I),{ }^{\circ} \mathrm{F}$ & 76.9 & 77.1 & 78.8 \\
\hline
\end{tabular}

$* 1$ - unacceptable level, extremely uncomfortable weather; $* 2$ - unsatisfactory level, uncomfortable weather; *3 satisfactory level, comfortable weather. 
The most uncomfortable area is the southern coast of the Crimean Peninsula, where the level of bioclimatic resources is unacceptable ( $D S \leq 0.20$ ); weather conditions are classified as extremely uncomfortable with moderate thermal load (Zone 1 in Fig. 4). Its area is $78.48 \mathrm{~km}^{2}(0.013 \%$ of the territory of Ukraine). The highest values of average temperature $\left(22.7^{\circ} \mathrm{C}\right)$, minimum temperature $\left(18.6^{\circ} \mathrm{C}\right)$, and maximum temperature $\left(27.1^{\circ} \mathrm{C}\right)$ are typical for this area. The records showed 90 summer days, 69 hot days, and 31 tropical nights. However, the absolute maximum duration of the hot period is 35 days, fewer than in Zone 2. Zone 1 also has the highest relative humidity (52.7\%), the most days with stuffiness - an average of 5 days per season - and the lowest wind speeds $\left(1.6 \mathrm{~m} \cdot \mathrm{s}^{-1}\right)$. Such a complex of weather conditions enhances the thermal load on the human body. The value of EET is close to the upper limit of comfort, i.e. $17.5^{\circ} \mathrm{C}$, and the PEET exceeds it by $5.5^{\circ} \mathrm{C}$.

For the rest of Ukraine, $61 \%$ of the country $\left(368,212 \mathrm{~km}^{2}\right)$, the values of $D S$ vary from 0.37 to 0.65 , indicating satisfactory levels of bioclimatic resources. Zone 3 is characterized by comfortable weather conditions for humans, with moderate thermal load. The average air temperature is $18.5^{\circ} \mathrm{C}$. The mean maximum reaches $24.4^{\circ} \mathrm{C}$, and the mean minimum is $13.2^{\circ} \mathrm{C}$. There are 76 summer days, with the fewest hot days (42 days per season). This area has the shortest duration of the hot period, only 15 days, half of that in an area with unsatisfactory heat levels and uncomfortable weather (Zone 2). For Zone 3, days with stuffiness or tropical nights are infrequent, averaging only 2 days per season. The region also has the lowest values of EET and PEET $\left(12.6^{\circ} \mathrm{C}\right.$ and $22.4^{\circ} \mathrm{C}$, respectively). Bioclimatic resources in this zone are favorable for the development of resort recreational activities in summer.

\section{Conclusions}

It is established that, depending on what factors or their complex is being considered, the same regions of Ukraine can be both comfortable and uncomfortable for humans. We have presented a method for integrated assessment of the seasonal level of comfort of climatic conditions and the degree of endowment with bioclimatic resources. The method employs comprehensive indicators that account for various aspects of the influence of meteorological conditions on the human thermal state, separately for the winter (DW) and summer (DS), using Harrington's desirability function. Based on these indicators, we have specified quantitative criteria, and boundaries of zones with different comfort levels and degree of endowment with bioclimatic resources in Ukraine. The locations of regions with comfortable and uncomfortable conditions, and their total area was determined.

Four zones were identified for the winter across Ukraine. In Zone 1, with unacceptably cold and extremely uncomfortable weather, there is the greatest influence of meteorological conditions on human health, heat load on the human body, and bodily heat loss. Zone 1 comprises the north-eastern regions of the country, the highlands of the Carpathians, and the Donetsk ridge, $7.26 \%$ of the total area of Ukraine. Zone 2, with unsatisfactory levels of indicators and uncomfortable weather makes up $41.78 \%$ of Ukraine. Zone 3, with satisfactory bioclimatic resources and comfortable weather, is the largest of all zones (49.61\% of Ukraine). Thus, winter meteorological conditions in Ukraine are mostly comfortable for the 
human thermal state. Zone 4, with good values of indicators and very comfortable weather, is only $1.35 \%$ of the territory: the southern region of Odessa, the western district of the Transcarpathian region, and the southern coast of Crimea.

In summer across Ukraine only 3 zones were identified. Zone 4, with good levels of indicators and very comfortable weather, was not highlighted by the $D S$ integrated index. Zone 1, with unacceptable levels of indicators and extremely uncomfortable weather occupies a small territory ( $0.013 \%$ of Ukraine) on the southern coast of the Crimean Peninsula that has extreme thermal stress. Zone 2, with unsatisfactory levels of indicators and uncomfortable weather makes up 38.98\% of Ukraine. Zone 3, with the satisfactory levels of bioclimatic resources and comfortable weather, as in winter, is also the largest of all zones. Across $61 \%$ of the territory of Ukraine in summer, meteorological conditions are comfortable for the human thermal state.

The main scientific findings of the study can be used to assess climate risks in the fields of tourism, recreation, medicine, balneology, and urban development. They should have importance in the development of strategies, programs, and measures to adapt to climate change. The results contribute to the expansion of scientific knowledge about the variability of weather and climatic comfort in the various regions of Ukraine and the state of bioclimatic resources of the country in the current climatic period.

\section{References}

Epstein Y., Moran D.S., 2006, Thermal comfort and the heat stress indices, Industrial Health, 44 (3), 388-398, DOI: 10.2486/indhealth. 44.388

Fröhlich D., Matzarakis A., 2015, A quantitative sensitivity analysis on the behaviour of common thermal indices under hot and windy conditions in Doha, Qatar, Theoretical and Applied Climatology, 124, 179-187, DOI: 10.1007/s00704-015-1410-5

Harrington E.C.,1965, The desirability function, Industrial Quality Control, 21, 494-498

Jendritzky G., Havenith G., Weihs P., Batchvarova E., DeDear R., 2007, The Universal Thermal Climate Index UTCI. Goal and state of COST Action 730, [in:] Bioclimatology and natural hazards, K. Strelcova, J. Skvarenina, M. Blazenec (eds.), International Scientific Conference, Polana nad Detvou, Slovakia, September 17-20

Kalkstein L.S., 2001, Biometeorology - looking at the links between weather, climate and health, WMO Bulletin, 2, 136-142

Kalkstein L.S., Davis R.S., 1989, Weather and human mortality: an evaluation of demographic and interregional responses in the United States, Annals of Association of American Geographers, 79 (1), 44-64, DOI: 10.1111/j.1467-8306.1989.tb00249.x

Kobysheva N.V., Stadnik V.V., Kljueva M.V., 2008, Manual of specialized climatological services for Economy, (in Russian), SPb, $336 \mathrm{pp}$.

Matthies F., Bickler G., Marin N.C, Hales S. (eds.), 2011, Action plans for protecting public health from the effects of heat waves, (in Russian), available online at http://www.euro.who.int/ data/assets/pdf file/0003/147873/E91347R.pdf (data access 09.08.2020)

Mohan M., Gupta A., Bhati S., 2014, A modified approach to analyze thermal comfort classification, Atmospheric and Climate Sciences, 4 (1), 7-19, DOI: $10.4236 /$ acs.2014.41002

OFCM, 2003, Report on wind chill temperature and extreme heat indices: evaluation and improvement projects, FCM-R19-2003, 75 pp., available online at https:/ / www.hsdl.org/?view\&did=22050 (data access 09.08.2020)

Siple P.A., Passel C.F., 1945, Measurements of dry atmospheric cooling in subfreezing temperatures, Proceedings of the American Philosophical Society, 89 (1), 177-199 
Stepanenko S.M., Pol'ovyy A.M. (eds.), 2011, The assessment of impact of climate change on the Ukraine industry, (in Ukrainian), Odessa: Ecology Publ., 696 pp.

Stepanenko S.M., Pol'ovyy A.M. (eds.), 2015, Climate change and its impact on sectors of the Ukraine economy, (in Ukrainian), Odessa: TES Publ., 520 pp.

Strategy of sustainable development "Ukraine - 2020", 2015, (in Ukrainian), available online at https://zakon.rada.gov.ua/laws/show/5/2015 (data access 09.08.2020) 